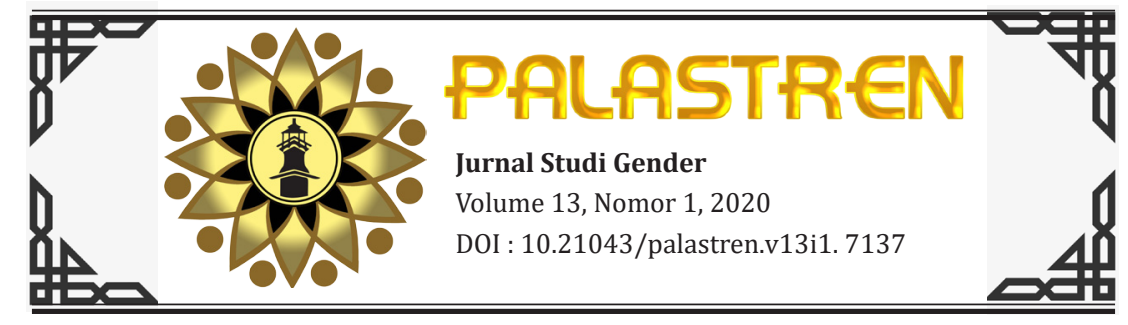

\title{
TRANSFORMASI SOSIAL-EKONOMI DAN PENDIDIKAN EKS-PEKERJA MIGRAN PEREMPUAN (PMP) DI SENDANG KABUPATEN TULUNGAGUNG
}

\author{
Chusnul Chotimah \\ Nur Isroatul Khusna \\ IAIN Tulungagung \\ chusnultata@iain-tulungagung.ac.id \\ ak.khusnaali@gmail.com
}

\section{ABSTRAK}

Rendahnya penghasilan dan minimnya lapangan kerja menyebabkan perempuan di Kecamatan Sendang Kabupaten Tulungagung nekat menjadi Pekerja Migran Perempuan (PMP). Impactnya adalah terjadinya transformasi sosial, ekonomi, dan pendidikan para eksPMP pasca kepulangannya dari luar negeri. Dengan menggunakan mix methods, artikel ini menggambarkan perubahan taraf kehidupan para mantan PMP dari sisi sosial, ekonomi dan pendidikan. Populasi dalam penelitian ini berjumlah 138 orang dengan sampel 100 responden. Hasil riset menunjukkan transformasi sosial terjadi ditandai dengan perubahan status sosial, pergeseran peran perempuan, pergeseran jenis pekerjaan PMP dari agraris menjadi non-agraris sebesar 34\%, dan perubahan life style. Transformasi ekonomi ditandai dengan meningkatnya penghasilan dari $54 \%$ tidak berpenghasilan turun menjadi $17 \%$ setelah menjadi PMP. Dan transformasi pendidikan ditandai dengan tumbuhnya kesadaran pengelolaan pendidikan dengan penyisihan anggaran sebesar $20 \%$ dari remitens untuk tabungan pendidikan.

Kata kunci: Transformasi sosial-ekonomi; Pendidikan; Pekerja Migran Perempuan. 


\section{ABSTRACT}

Low income and lack of employment causes women in Sendang Tulungagung District to be desperate to become Female Migrant Workers (FMW) which resulted in social, economic, and educational transformation of ex-FMWs after their return from abroad. Using mix methods, this article illustrates the changes in the standard of living of former FMWs in terms of social, economic and educational aspects. The population are around 138 people with sample 100 respondents. The results showed that social transformation occurred marked by changes in social status, shifting the role of women, shifting the types of FMW jobs from agrarian to non-agrarian by $34 \%$, and changes in life style. Economic transformation is marked by an increase in income from $54 \%$ of non-income down to $17 \%$ after becoming FMW. In addition, the transformation of education is marked by the growing awareness of education management with a budget allowance of $20 \%$ of remittances for education savings.

Keywords: Social-Economic transformation; Education management; Migrant Workers Women.

\section{A. Pendahuluan}

Indonesia adalah negara yang memiliki jumlah penduduk keempat terbesar di dunia. Jumlah penduduk Indonesia pada tahun 2010 kurang lebih sebanyak 238,5 juta jiwa dengan proyeksi pada tahun 2035 jumlah penduduk Indonesia kurang lebih sebanyak 305,6 juta jiwa. Rata-rata laju pertumbuhan penduduk Indonesia per tahun selama periode tahun 2015 sampai 2020 sebesar 1,20\% dan mengalami penurunan dalam kurun waktu lima tahunan hingga 0,62\%. (BPS, 2013: 23-25). Hal ini berarti setiap tahun jumlah penduduk Indonesia bertambah 3 sampai 4 juta orang dari total jumlah penduduk. Pertambahan jumlah penduduk yang cukup tinggi ini memiliki implikasi terhadap perkembangan angkatan kerja serta kesempatan kerja di Indonesia untuk masa yang akan datang. Laju perkembangan penduduk yang tidak diimbangi dengan penciptaan lapangan kerja yang seimbang akan mengakibatkan bertambahnya angka kemiskinan. Menurut data yang diperoleh dari BPS Jawa Timur, 
pada tahun 2017 Provinsi Jawa Timur menempati peringkat pertama dalam masalah kemiskinan se-Jawa yakni 4.405,27 ribu jiwa atau sekitar 11,2\% dari total kemiskinan sebanyak 26.582,99 ribu jiwa pada tahun tersebut (www.bps.go.id).

Berdasarkan fenomena di atas, maka sebagian penduduk perempuan yang sulit mendapatkan pekerjaan di dalam negeri berupaya mengatasinya dengan memilih bekerja ke luar negeri sebagai Pekerja Migran Perempuan (PMP). Mereka bekerja dengan harapan dapat membantu meningkatkan pendapatan keluarga yang akhirnya dapat memperbaiki tingkat sosial ekonomi yang berguna juga untuk pembangunan bangsa.

Keikutsertaan perempuan dalam pembangunan bangsa, salah satunya adalah dengan berpartisipasi dalam mengatasi kesulitan perekonomian keluarganya. Selain itu, disadari atau tidak, dengan bekerja sebagai PMP ke luar negeri mereka juga membantu menambah devisa bagi negara. Selain itu perempuan mempunyai kemampuan yang tak terhingga misalnya dalam menumbuhkan keluarga sejahtera, mendidik anak serta mendampingi suami dalam membina karier. Menurut konsep gender, perempuan sejajar dan memiliki kesempatan yang sama dengan pria dalam meniti jenjang kariernya. Seiring bertambahnya waktu, Indonesia sudah menerapkan konsep kesetaraan gender. Pada tahun 2015 indeks pemberdayaan gender mencapai angka 68,41\% dan untuk Provinsi Jawa Timur angka tersebut mengalami kenaikan dan penurunan dari tahun sebelumnya, yaitu pada tahun 2013 dengan indeks sebesar 70,77\% dan pada tahun 2014 sebesar 68,17\% (Budijanto, dkk, 2017: 11-12).

Selain itu, upaya melibatkan perempuan dalam proses pembangunan bukanlah semata berdasarkan pertimbanganpertimbangan manusiawi, melainkan juga dianggap sebagai pilihan yang rasional dan tindakan yang efisien. Dalam pandangan Mansour Fakih (2005: 8), masalah gender sesungguhnya bukan semata tanggung jawab negara, meskipun pemerintah Indonesia telah menetapkan isu gender dalam semua program pembangunan yang berkelanjutan (sustainable 
development goals) pada setiap aspek. Sebab gender adalah suatu konsep yang mengacu pada peran dan tanggung jawab laki-laki dan perempuan sebagai hasil konstruksi sosial dan kultural yang dapat diubah sesuai dengan perubahan zaman.

Dalam pengertian yang lain, gender merupakan sebuah konsep yang mengacu pada peran dan tanggung jawab perempuan dan laki-laki yang diciptakan dalam keluarga, masyarakat, dan budaya. Konsep gender juga mencakup harapan yang dimiliki tentang karakteristik, bakat, dan kemungkinan perilaku perempuan dan laki-laki (feminin dan maskulin) dalam sebuah relasi dan tatanan masyarakat yang setara. Berbeda dengan seks, gender tidak ada kaitannya dengan perbedaan jenis kelamin secara biologis (Candida March, 1999: 17).

Kabupaten Tulungagung adalah salah satu kabupaten di Jawa Timur yang secara astronomis terletak antara $111^{\circ} 43^{\prime \prime}$ BT$112^{\circ} 07^{\prime \prime}$ BT dan $7^{\circ} 50^{\prime \prime}$ LS-8 ${ }^{\circ} 20^{\prime \prime}$ LS denganluas wilayah 1.046 .257 km² atau 2,2\% dari luas Provinsi Jawa Timur. Kabupaten Tulungagung adalah wilayah yang sebagian besar penduduknya bekerja sebagai TKI ke luar negeri. Bila dibandingkan dengan kabupaten lainnya di Jawa Timur, Tulungagung merupakan penyumbang TKI lima besar di provinsinya. Sedangkan di Kabupaten Tulungagung sendiri, berdasarkan data dari Buku Informasi dan Profil Dinaketrans (2017:16) jumlah TKI di luar negeri pada tahun 2017 sejumlah 3.861. Untuk klasifikasinya, jumlah TKI yang terdata Badan Nasional Penempatan dan Perlindungan Tenaga Kerja Indonesia (BNP2TKI) untuk Kabupaten Tulungagung tahun 2018 sebanyak 7.108 orang dengan perbandingan laki-laki 23\% perempuan 77\% (www. bnp2tki.go.id). Jika dilihat dari angka tersebut, duapertiga tenaga kerja dari Kabupaten Tulungagung yang bekerja di luar negeri adalah perempuan.

Hal tersebut sesuai dengan data yang disajikan oleh BPS dimana Indeks Pemberdayaan Gender (IDG) Kabupaten Tulungagung terus mengalami kenaikan. Berikut adalah IDG Kabupaten Tulungagung (www.jatim.bps.go.id): 
Tabel 1. Indeks Pemberdayaan Gender Kabupaten Tulungagung

\begin{tabular}{ccc}
\hline No & Tahun & IDG \\
\hline 1 & 2014 & 95.11 \\
2 & 2015 & 95.07 \\
3 & 2016 & - \\
4 & 2017 & 95.30 \\
5 & 2018 & 95.75 \\
\hline & Rata-rata & 95.30
\end{tabular}

Data tersebut menunjukkan IDG di Kabupaten Tulungagung yang tinggi dan mengalami peningkatan dalam tiap tahunnya. Angka 95.30 merupakan angka yang mendekati skala 100, dan menunjukkan perempuan di Kabupaten Tulungagungmemiliki peran yang tinggi dalam pembangunan, yang mengindikasi pula minimnya kesenjangan pembangunan antara laki-laki dan perempuan.

Kabupaten Tulungagung dengan 19 kecamatan, salah satunya adalah Kecamatan Sendang yang memiliki 11 desa. Jumlah penduduk di Kecamatan Sendang tahun 2015 sebanyak 46.756 jiwa. Kecamatan Sendang merupakan salah satu kawasan yang berada di sebelah Barat laut Kabupaten Tulungagung yang terletak di daerah pegunungan: berada di lereng Gunung Wilis dan sebagian besar penduduknya menjadi TKI ke luar negeri. Adanya provokasi, kemudahan dan iming-iming gaji menggiurkan yang ditawarkan oleh para calo dan agen tenaga kerja pada akhirnya kian memperkuat transformasi tenaga kerja ke sektor ini. Setidaknya ada lima negara tujuan favorit para PMP asal Sendang: Taiwan, Korea Selatan, Hongkong, Malaysia, dan Singapura. Dalam hal ini, Taiwan menempati urutan paling atas jumlah sebanyak 98 orang. Sedangkan urutan kedua adalah Hongkong sebanyak 17 orang. Dilanjutkan ke Singapura sebanyak 12 orang, Malaysia sebanyak 7 orang dan ke Korea Selatan sebanyak 4 orang. Jumlah keseluruhan mantan PMP sebanyak 138 orang. Untuk mempermudah, berikut gambaran umum tabel jumlah mantan PMP dari Kecamatan Sendang yang pernah bekerja ke luar negeri dan memutuskan untuk tidak bekerja lagi ke sana. 
Tabel 2 Jumlah Persebaran Mantan PMP (periode 2012-2015) Tiap Desa yang bekerja luar negeri di Kecamatan Sendang

\begin{tabular}{llcccccc}
\hline \multirow{2}{*}{ No } & \multicolumn{6}{c}{ Desa } & \multicolumn{7}{c}{ Negara Tujuan } & Jumlah \\
\cline { 3 - 7 } & Taiwan & $\begin{array}{c}\text { Korea } \\
\text { Selatan }\end{array}$ & Hong-kong & Malaysia & Singapura & \\
\hline 1. & Dono & 28 & 1 & 4 & 2 & 2 & 37 \\
2. & Sendang & 16 & 1 & 1 & - & 3 & 21 \\
3. & Krosok & 10 & 1 & 2 & 1 & 1 & 15 \\
4. & Kedoyo & 8 & - & 2 & 2 & - & 12 \\
5. & Tugu & 7 & 1 & 4 & - & - & 12 \\
6. & Geger & 7 & - & 1 & 1 & 1 & 10 \\
7. & Nyawangan & 6 & - & - & 1 & 2 & 9 \\
8. & Talang & 4 & - & 1 & - & 2 & 7 \\
9. & Picisan & 5 & - & 1 & - & - & 6 \\
10. & Nglutung & 4 & - & 1 & - & - & 5 \\
11. & Nglurup & 3 & - & - & - & 1 & 4 \\
\hline Total & & 98 & $\mathbf{4}$ & $\mathbf{1 7}$ & $\mathbf{7}$ & $\mathbf{1 2}$ & $\mathbf{1 3 8}$ \\
\hline
\end{tabular}

Sumber: Data Kantor Kecamatan Sendang

Berangkat dari realitas di atas, maka artikel ini fokus pada transformasi sosial, ekonomi, dan pendidikan PMP pasca bekerja di Luar Negeri, dan faktor-faktor apa saja yang memengaruhinya berangkat ke sana. Analisa dalam usaha untuk menemukan jawaban terhadap permasalahan tersebut dilandasi oleh asumsi dasar bahwa setiap mobilitas selalu dilakukan dengan tujuan tertentu yang akhirnya setelah melakukan mobilitas akan mempengaruhi keadaan sosial, ekonomi, dan pendidikan.

Penelitian ini berbentuk deskriptif kuantitatif dengan menggunakan metode survey berupa angket danjuga dilengkapi wawancara, observasi, dan dokumentasi sehingga penelitian ini masuk dalam kategori mix methods. Hal ini sejalan dengan definsi mix methods sebagai sebuah prosedur penelitian untuk menggali dan analisis data dengan menggabungkan antara metode kuantitatif dan kualitatif untuk memahami sebuah permasalahan (Creswell, 2012: 12). 
Populasi dalam penelitianini adalah keluarga yang terdapat mantan PMP yang bekerja di luar negeri pada kurun waktu 2012 sampai 2015 yang saat penelitian ini dilakukan telah kembali ke daerah asalnya dan belum atau tidak bekerja lagi sebagai PMP ke luar negeri, agar bisa diukur tingkat perubahan sebagai hasil dari PMP. Jumlah mantan PMP tersebut adalah 138 orang dari 138 KK PMP di Kecamatan Sendang Kabupaten Tulungagung. Dari jumlah populasi 138 diambil 100 menggunakan proporsional random sampling.

Tabel 3. Data Sebaran Sampel Penelitian Mantan PMP Tiap Desa yang bekerja luar negeri di Kecamatan Sendang periode Tahun 2012-2015

\begin{tabular}{|c|c|c|c|c|c|c|c|c|c|}
\hline \multirow{2}{*}{ No } & \multirow{2}{*}{ Desa } & \multicolumn{5}{|c|}{ Negara Tujuan } & \multirow{2}{*}{$\begin{array}{l}\text { Jumlah } \\
\text { (jiwa) }\end{array}$} & \multirow{2}{*}{ Jumlah KK } & \multirow{2}{*}{ Sampel } \\
\hline & & $\mathrm{T}$ & K & $\mathrm{H}$ & $\mathrm{M}$ & $\mathrm{S}$ & & & \\
\hline 1. & Dono & 28 & 1 & 4 & 2 & 2 & 37 & 37 & 27 \\
\hline 2. & Sendang & 16 & 1 & 1 & - & 3 & 21 & 21 & 15 \\
\hline 3. & Krosok & 10 & 1 & 2 & 1 & 1 & 15 & 15 & 11 \\
\hline 4. & Kedoyo & 8 & - & 2 & 2 & - & 12 & 12 & 9 \\
\hline 5. & Tugu & 7 & 1 & 4 & - & - & 12 & 12 & 9 \\
\hline 6. & Geger & 7 & - & 1 & 1 & 1 & 10 & 10 & 7 \\
\hline 7. & Nyawangan & 6 & - & - & 1 & 2 & 9 & 9 & 6 \\
\hline 8. & Talang & 4 & - & 1 & - & 2 & 7 & 7 & 5 \\
\hline 9. & Picisan & 5 & - & 1 & - & - & 6 & 6 & 4 \\
\hline 10. & Nglutung & 4 & - & 1 & - & - & 5 & 5 & 4 \\
\hline 11. & Nglurup & 3 & - & - & - & 1 & 4 & 4 & 3 \\
\hline & Total & 98 & 4 & 17 & 7 & 12 & 138 & 138 & 100 \\
\hline
\end{tabular}

Catatan: $\quad \begin{aligned} \mathrm{T} & =\text { Taiwan } \\ \mathrm{K} & =\text { Korea } \\ \mathrm{H} & =\text { Hongkong } \\ \mathrm{M} & =\text { Malaysia } \\ \mathrm{S} & =\text { Singapura }\end{aligned}$

Instrumen yang digunakan dalam penelitian ini adalah kuesioner. Instrumen ini dilakukan dengan cara wawancara terstruktur dengan berpedoman pada kuesioer. Jenis kuesioner 
yang digunakan berupa jenis kuesioner terbuka dan tertutup yang isinya meliputi data tentang tingkat pendidikan, tingkat pendapatan, jenis pekerjaan, status perkawinan, usia dan pendapatan kepala keluarga.

Dalam penelitian ini, data yang digunakan berupa data primer dan data sekunder. Data primer meliputi data yang diperoleh langsung dari wawancara yang berupa tingkat pendidikan, tingkat pendapatan, jenis pekerjaan, status perkawinan, usia dan pendapatan kepala keluarga PMP. Sedangkan data sekunder diperoleh dari dokumen-dokumen maupun arsip-arsip dari lembaga terkait yang ada di Kabupaten Tulungagung: Dinsosnakertrans, BPS dan Kantor Kecamatan Sendang. Data sekunder ini berupa data tentang kondisi daerah penelitian, jumlah PMP dan negara tujuan PMP yang berasal dari Kecamatan Sendang Kabupaten Tulungagung.

Teknik pengumpulan data dalam penelitian ini menggunakan tiga teknik, yaitu teknik observasi, teknik wawancara, dan teknik dokumentasi. Observasi dalam penelitian ini digunakan untuk mengetahuikeadaangeografis daerah penelitian. Teknikwawancara ini digunakan untuk memeroleh data dengan menggunakan kuesioner sebagai instrumennya yaitu kuesioner terbuka dan tertutup dengan cara wawancara terstruktur. Sedangkan teknik dokumentasi digunakan untuk memperoleh data dengan atau mengutip dari beberapa catatan atau dokumentasi dari suatu uraian atau keadaan. Adapun data yang diperlukan terdiri dari peta lokasi dan daerah penelitian, data kependudukan, serta datadata lain yang menunjang penelitian ini.

Sedangkan untuk analisis, menggunakan deskriptif kuantitatif. Oleh karena itu, analisis deskriptif yang digunakan adalah tabulasi tunggal dan presentase. Analisis yang digunakan dalam penelitian ini bertujuan untuk mengetahui gambaran karakterisik setiap variabel dan menemukan suatu jawaban guna menarik kesimpulan hasil penelitian. Dengan demikian rumus presentase yang digunakan adalah:

$$
P=\frac{f}{n} \times 100 \%
$$


Keterangan:

$\mathrm{P}=$ Prosentase

$\mathrm{f}=$ frekuensi seringnya muncul tiap jawaban

$\mathrm{n}=$ banyaknya responden

\section{B. Pembahasan}

Studi tentang fenomena tenaga kerja Indonesia ditinjau dari berbagai perspektif memang bukan hal baru. Namun meski begitu, masih banyak bagian-bagian yang belum tersentuh dan perlu disuguhkan ke dalam diskursus ruang publik (public sphere) akademik, di antaranya adalah transformasi sosial, ekonomi, dan pendidikan.

\section{Transformasi Sosial PMP di Sendang Kabupaten Tulungagung}

Peningkatan Pekerja Migran Perempuan di Sendang Kabupaten Tulungagung, bukan tanpa alasan mendasar, melainkan karena diawali dari faktor pemenuhan kebutuhan ekonomi, sementara lapangan pekerjaan tidak mendukung, demikian pula potensi sumber daya manusia lemah. Dengan dalih memenuhi kebutuhan ekonomi inilah, para perempuan terutama yang berstatus sebagai istri akhirnya memutuskan untuk pergi ke luar negeri menggantikan peran suami sebagai kepala keluarga.

Nilai-nilai kemasyarakatan bahwa perempuan identik dengan urusan dapur, mengasuh anak, serta menjadi konco wingking bagi laki-laki yang selama ini masih kental menjadi terkikis dan nyaris sudah tak berlaku lagi. Fenomena di lapangan didapatkan bahwa mayoritas kaum lelaki (suami) mengijinkan perempuan untuk bekerja ke Luar Negeri, sementara mereka mengolah lahan/sawah atau bahkan kedua-keduanya sebagai pekerja migran. Dari 100 responden yang di dapat ada 51\% yang keduanya sama-sama pernah sebagai pekerja migran. (Wawancara: Tokoh masyarakat, 2018). 
Fenomena tersebut jika dikaji dari perspektif gender, sesungguhnya telah terjadi pergeseran relasi gender dalam konteks keluarga PMP. Artinya bahwa domestifikasi perempuan yang patriarkis sudah tak berlaku lagi. Sejalan dengan pendapat Mosser, seperti yang dikutip Narwoko dan Bagong, bahwa perempuan tidak saja berperan ganda, akan tetapi perempuan memiliki triple role: peran reproduksi alias peran yang berhubungan dengan peran tradisional di sektor domestik; peran produktif yaitu peran ekonomis disektor publik, dan peran sosial, yaitu peran di komunitas (Narwoko, \& Sunyoto, 2006: 345).

Tanpa disadari peran sebagai penopang keluarga telah diambil alih oleh perempuan, dan hal ini menjadikan pengambil keputusan keluarga berpindah ke pihak yang lebih berkuasa, yaitu perempuan. Pergeseran peran tersebut didukung oleh keberhasilan PMP yang mengalami perubahan status pekerjaan dari semula pekerja domestik 35\% setelah menjadi PMP turun menjadi $17 \%$. Dan ada dua jenis pekerjaan yang ditinggalkan setelah menjadi PMP, yaitu sebagai Ibu Rumah Tangga (IRT) dan tidak bekerja/ pengangguran. Secara terperinci sebagaimana data berikut:

\section{a. Jenis Pekerjaaan Sebelum dan Sesudah Menjadi PMP}

Jenis pekerjaan adalah segala sesuatu pekerjaan yang dilakukan, baik pekerjaan pokok maupun pekerjaan sampingan yang bertujuan untuk memenuhi kebutuhan hidupnya. PMP yang pernah bekerja di luar negeri dari Kecamatan Sendang, tidak semuanya berangkat dengan pengalaman yang kosong. Sebagian dari mereka ada yang sudah pernah bekerja namun karena pendapatannya dianggap kurang, akhirnya memutuskan untuk mencari alternatif ke luar negeri. Mereka ada yang bertani, buruh karyawan pabrik dan sebagainya. Penghasilan dan gaji mereka hanya cukup untuk memenuhi kebutuhan keluarga sehari-hari. 
Data lengkap mengenai jenis pekerjaan responden perempuan yang pernah bekerja di luar negeri dapat dilihat di tabel 4 sebagai berikut.

Tabel 4. Jenis Pekerjaan Sebelum Menjadi PMP di Luar Negeri

\begin{tabular}{clcc}
\hline \multirow{2}{*}{ No } & $\begin{array}{l}\text { Jenis Pekerjaan Sebelum Menjadi } \\
\text { PMP di Luar Negeri }\end{array}$ & f & $\%$ \\
\cline { 4 - 4 } 1 & Buruh tani & 13 & 13.0 \\
2 & IRT (Ibu Rumah Tangga) & 35 & 35.0 \\
3 & Karyawan pabrik & 7 & 7.0 \\
4 & Karyawan swasta & 2 & 2.0 \\
5 & Penjaga took & 10 & 10.0 \\
6 & Penjahit & 9 & 9.0 \\
7 & PRT (Pembantu Rumah Tangga) & 5 & 5.0 \\
8 & Tidak bekerja & 19 & 19.0 \\
\hline & Jumlah & 100 & 100.0 \\
\hline
\end{tabular}

Menurut tabel di atas, dapat dijelaskan bahwa PMP di Kecamatan Sendang sebelum bekerja di luar negeri sebagian besar sudah mempunyai pekerjaan dengan jenis pekerjaan sebagai Ibu Rumah Tangga (IRT): 35,0\%, buruh tani: 13,0\%, penjaga toko: 10,0\%, penjahit: $9,0 \%$, karyawan pabrik: 7,0\%, pembantu rumah tangga: 5,0\%, karyawan swasta: 2,0\% dan selebihnya 19 $\%$ belum bekerja. Dari data tersebut, menggambarkan bahwa mereka kebanyakan bekerja sebagai ibu rumah tangga, karena bila ingin bekerja yang lebih baik harus berbekal ijazah yang memadai. Hal ini dikarenakan adanya keterkaitan antara tingkat pendidikan dengan jenis pekerjaan yang diperoleh PMP sebelum bekerja di luar negeri dan akan membawa kaitan pula terhadap keputusannya bekerja di sektor yang lebih baik guna pemenuhan kebutuhan hidup yang lebih baik pula.

Sedangkan jenis pekerjaan pascabekerja dari luar negeri yang dimaksud adalah jenis pekerjaan PMP setelah 
kembali ke daerah asal. Berdasarkan hasil penelitian yang didapatkan dari responden, jenis pekerjaan pascabekerja di luar negeri adalah seperti terdapat dalam tabel 5 berikut:

Tabel 5. Jenis Pekerjaan Pasca Bekerja di Luar Negeri

\begin{tabular}{clcc}
\hline \multirow{2}{*}{ No } & $\begin{array}{l}\text { Jenis Pekerjaan Pasca Bekerja } \\
\text { di Luar Negeri }\end{array}$ & F & $\%$ \\
\cline { 4 - 4 } & Buruh pabrik & 10 & 10.0 \\
2 & Dagang & 28 & 28.0 \\
3 & IRT & 17 & 17.0 \\
4 & Penjahit & 10 & 10.0 \\
5 & Perikanan & 2 & 2.0 \\
6 & Petani & 15 & 15.0 \\
7 & Peternak & 11 & 11.0 \\
8 & Swasta/lainnya & 7 & 7.0 \\
\hline
\end{tabular}

Dari data yang terdapat pada tabel 5 di atas, jenis pekerjaan pasca bekerja di luar negeri yang terbanyak adalah dagang yaitu sebanyak 28 responden $(28,0 \%)$. Sedangkan untuk jenis pekerjaan pasca responden bekerja di luar negeri yang paling sedikit adalah swasta/ lainnya yaitu sebanyak tujuh responden (7,0\%). Swasta/ lainnya dalam penelian ini adalah jenis usaha yang termasuk dalam sektor industri yaitu yang meliputi industri rumah tangga, industri kecil, industri sedang maupun industri besar. Perbedaan jenis pekerjaan PMP pascabekerja di luar negeri sangat dipengaruhi oleh bakat, minat, keterampilan, dan faktor pendidikan PMP serta besar kecilnya modal yang digunakan.

Maka jika dibandingkan dengan jenis pekerjaan sebelum bekerja ke luar negeri terjadi perubahan ke arah yang lebih baik. Jika sebelum berangkat ke luar negeri jenis pekerjaan PMP yang paling banyak adalah sebagai ibu rumah tangga yaitu sebesar 35\% dengan jumlah 
responden sebanyak 35 orang maka setelah bekerja di luar negeri jenis pekerjaan yang terbanyak adalah pedagang yaitu sebesar $28 \%$ dengan responden sebanyak 28 orang. Untuk tenaga kerja yang pascabekerja di luar negeri berperan sebagai ibu rumah tangga adalah sebesar $17 \%$ yaitu sebanyak 17 responden. Jadi terdapat penurunan sebesar 18\% terhadap jumlah ibu rumah tangga sebelum bekerja di luar negeri dan setelah bekerja di luat negeri.

Perubahan jenis pekerjaan tersebut di atas menyebabkan perubahan peran dalam relasi sosial perempuan. Ditambah perubahan kelayakan tempat tinggal menjadikan pergeseran status sosial semakin terlihat nyata. Dari semula belum memiliki tempat tinggal menjadi pemilik rumah, dari semula buruh pekerja sawah menjadi pemilik sawah, dari tidak memiliki usaha menjadi pemilik usaha.

\section{b. Tempat Tinggal di Daerah Lain Pasca Bekerja di Luar Negeri}

Tempat tinggal di daerah lain adalah kepemilikan rumah atau tempat singgah pribadi PMP pasca kepulangannya dari luar negeri, selain tempat tinggal atau rumah yang berada di desa asal. Berdasarkan hasil penelitian yang didapatkan dari keterangan responden, kepemilikan tempat tinggal atau rumah lain selain di desa asal pasca bekerja di luar negeri adalah seperti terdapat dalam tabel 8 berikut:

\section{Tabel 8. Kepemilikan Rumah Selain di Desa Asal}

\begin{tabular}{clcc}
\hline No & Kepemilikan Rumah Selain di Desa Asal & F & $\%$ \\
\cline { 4 - 5 } \multicolumn{1}{c}{1} & Tidak memiliki tempat tinggal di daerah lain & 86 & 86.0 \\
2 & Ya, di desa lain dalam satu kecamatan & 5 & 5.0 \\
3 & Ya, di luar kabupaten & 2 & 2.0 \\
4 & Ya, di luar kecamatan namun satu kabupaten & 7 & 7.0 \\
\hline & Jumlah & 100 & 100.0 \\
\hline
\end{tabular}


Dari data yang terdapat dalam tabel di atas, dapat diketahui bahwa sebanyak 86 responden $(86,0 \%)$ tidak memiliki tempat tinggal di daerah lain. Sebagian besar hal ini disebabkan karena tanah yang ada di sekitar mereka masih cukup luas untuk mendirikan ataupun memperluas tempat tinggal dan adanya keinginan untuk tetap tinggal di daerah asalnya. Sedangkan sebanyak dua responden $(2,0 \%)$ yang merupakan kelompok responden dengan prosentase terkecil memiliki tempat tinggal lain yang berada di luar kecamatan.

Dengan demikian dapat ditarik kesimpulan bahwa sebanyak $14 \%$ dari total responden mempunyai tempat tinggal lain selain di daerah asal baik masih dalam satu kecamatan ataupun di luar kabupaten. Tingkat penghasilan yang lebih dan hasil kerja yang besar oleh $14 \%$ responden digunakan untuk memenuhi kebutuhan papan di daerah lain yang tentunya mempunyai nilai jual yang lebih tinggi karena mayoritas tempat tinggal lain tersebut berada di dekat pusat kota. Sedangkan Kecamatan Sendang adalah daerah yang berada di lereng Gunung Wilis dengan struktur wilayah yang tidak rata (daerah pegunungan).

Perubahan jenis pekerjaan dan juga tempat tinggal menjadikan status sosial PMP mengalami pergeseran. Peran di dalam keluarga yang bukan lagi konco wingking, cara berhubungan dengan masyarakat, relasi dengan komunitas sesama PMP, ketaatan terhadap nilainilai kultur di lingkungan, hingga life style semuanya mengalami pergeseran. Perempuanturutserta mengambil kebijakan di keluarga, relasi dengan komunitas luas, life style sudah terkontaminasi dengan budaya luar negeri, hingga nilai-nilai kultur menjadi pudar karena kesibukan aktifitas yang dilakukan para perempuan yang bukan lagi hanya berprofesi sebagai ibu rumah tangga. Nilai gotong royong dalam paguyuban sekarang sudah mulai pudar. Tenaga sudah diukur dengan uang. Para lelaki 
mengasuh anak tatkala ditinggal PMP bukan lagi hal yang aneh. (Wawancara: Suud, 2018).

Data tersebut jika dikaji dalam konteks relasi gender, menurut Nancy Cook [ed.], (2007:1), hal demikian terjadi lantaran adanya sebuah hubungan kompleks yang melibatkan aspek kultural dan historis dalam sistem dan nilai sosial masyarakat antara perempuan dan lakilaki. Sebagai sistem sosial, relasi gender adalah prinsip pengorganisasian utama masyarakat yang sebagian mengatur tentang proses produksi dan reproduksi, konsumsi, dan distribusi sumberdaya. Maka relasi gender tidak beroperasi secara terpisah, tetapi dipengaruhi dan dibentuk oleh sistem lain yang mengatur interaksi sosial antara kelompok-kelompok orang, termasuk ekonomi, seksualitas, "ras," dan skill.

Secara lebih jelas, kepergian ibu menjadi PMP menjadikan perubahan struktur dalam keluarga yang tadinya merupakan struktur keluarga utuh (intactfamilies) menjadi keluarga yang tidak utuh dengan kepala keluarga laki-laki untuk sementara waktu. (Observasi, 2018). Hal ini menjadikan pergeseran peran perempuan dan laki-laki dalam keluarga yang tadinya sektor domestik dilimpahkan kepada perempuan beralih kepada laki-laki. Tyas Retno Wulan, dkk., juga sejalan dengan riset Lam, Yeoh, dan Hoang (2013) di Asia Tenggara menjelaskan saat keberangkatan seseorang yang menjadi pekerja migran akan berpengaruh terhadap anggota keluarga yang ditinggalkan, sebab ada perubahan peran dalam keluarga untuk menggantikan anggota keluarga yang menjadi pekerja migran (Tyas Retno Wulan, dkk, 2018: 86). Disinilah pergeseran peran terjadi.

Disisi lain pergeseran status sosial juga terjadi. PMP menjadi naik kelas sosial di masyarakat dengan salah satu ukurannya adalah kepemilikan harta. Pasca menjadi PMP mayoritas memiliki sawah, kendaraan, dan membanggun rumah. Namun tanpa disadari 
pengelolaan keuangan hasil bekerja sebagai PMP tersebut banyak yang bersifat non produktif. Naiknya kelas sosial ini juga mempengaruhi life style PMP, yang meliputi 3F, yaitu food, fashion, dan fun. Pergeseran 3F ini menjadikan melemahnya norma-norma sosial yang telah disepakati bersama di kecamatan Sendang, demikian pula dengan kontrol sosial dikarenakan adanya infiltrasi nilai yang dibawa dari luar negeri diterapkan di pedesaaan.

Infiltrasi nilai merubah nilai-nilai paguyuban bergeser pada kebutuhan yang bersifat personal yang diukur dengan nominal bukan lagi intimate. Nilai sosial yang dulu dibangun berdasar ikatan antar sesama secara personal-sentimental dan kegiatan masyarakat bersifat informal-tradisional bergeser menjadi ikatan impersonalrealistik dengan kegiatan yang dibangun bersifat formalutilitarian. (Soekanto, 2010: 116).Disinilah transformasi sosial dimulai.

Transformasi sosial ini sebagaimana pendapat Wilkes yang menyatakan bahwa transformasi sosial ditandai dengan naiknya kelas sosial PMP dengan kepemilikan benda atau barang (Wilkes, 2005: 139). Kelas sosial tidak hanya mengacu pada kepemilikan modal ekonomi, tetapi juga tentang banyak praktik kelas yang meliputi selera makan, cara berpakaian, disposisi tubuh, model rumah, dan beragam pilihan sosial dalam kehidupan sehari-hari. Fenomena inilah yang terjadi di kecamatan Sendang, dimana kesuksesan seseorang dimaknai dengan naiknya kelas sosial sebagai standar hidup atau lebih eksplisit lagi bermakna kekayaan atau aspek material dengan melemahkan aspek nilai-nilai kultur masyarakat secara immaterial.

\section{Transformasi Ekonomi PMP Sendang}

Sisi lain yang menjadi kajian utama dari mantan PMP di Kecamatan Sendang adalah keberhasilannya dalam menghimpun pundi-pundi ekonomi dan melakukan usaha 
kreatif ekonomi keluarga. Dari 100 responden rata-rata mengalami peningkatan ekonomi 20\% jika dibanding sebelum menjadi PMP. Bahkan para mantan PMP di Kecamatan Sendang telah terbuka wawasannya dengan mengelola hasil jerih payah selama menjadi PMP dengan membuka usaha ekonomi, baik di desa tempat tinggalnya ataupun di luar desa yang lebih menguntungkan secara ekonomi.

\section{a. Pendapatan PMP Sebelum dan Sesudah Bekerja di Luar Negeri}

Tingkat pendapatan adalah jumlah penghasilan bersih yang diperoleh selama satu bulan dari pekerjaan PMP sebelum bekerja di luar negeri yang diukur dalam rupiah/bulan. Gambaran tingkat pendapatan responden masyarakat Kecamatan Sendang dapat dilihat pada Tabel 6 berikut.

\section{Tabel 6. Pendapatan PMP Sebelum Bekerja di Luar Negeri}

\begin{tabular}{clcc}
\hline \multirow{2}{*}{ No } & Pendapatan PMP Sebelum Bekerja & F & $\%$ \\
& di Luar Negeri & & \\
\cline { 3 - 4 } 1 & Tidak Berpenghasilan & 54 & 54.0 \\
2 & Rp.300.000,00-<Rp.400.000,00 & 12 & 12.0 \\
3 & Rp.400.000,00-<Rp.500.000,00 & 17 & 17.0 \\
4 & Rp.500.000,00-<Rp.600.000,00 & 9 & 9.0 \\
5 & Rp.600.000,00-<Rp.700.000,00 & 4 & 4.0 \\
6 & Rp.700.000,00-Rp.800.000,00 & 3 & 3.0 \\
7 & $>$ Rp.800.000,00 & 1 & 1.0 \\
\hline & Jumlah & 100 & 100.0 \\
\hline
\end{tabular}

Dari tabel di atas diperoleh penjelasan bahwa tingkat pendapatan per bulan dari responden. Dari pendapatan tersebut dikelompokkan menjadi 4 kategori, yaitu kategori berpendapatan tinggi, sedang, sedikit, dan tidak berpenghasilan. Perhitungan pengelompokan besarnya pendapatan tersebut memperhatikan 
pendapatan tertinggi responden sebagai batas maksimum dan pendapatan terendah sebagai batas minimum. Responden yang berpenghasilan tinggi yaitu Rp.700.000,00 atau lebih sebanyak 4 responden $(4.0 \%)$, berpendapatan sedang yaitu antara Rp. 500.000,00 sampai kurang dari Rp. 700.000,00 sebanyak 13 responden $(13,0 \%)$, berpendapatan sedikit yaitu antara Rp. 300.000,00 sampai kurang dari Rp. 500.000,00 sejumlah 29 responden $(29,0 \%)$ dan selebihnya sebanyak 54 responden $(54,0 \%)$ belum punya penghasilan dan merupakan frekuensi terbanyak tingkat penghasilan responden. Perbedaan tingkat penghasilan responden dikarenakan oleh perbedaan jenis pekerjaan responden.

Sedangkan di sisi lain, tingkat pendapatan pasca bekerja di luar negeri adalah jumlah pendapatan bersih yang diperoleh selama satu bulan dari pekerjaan PMP setelah bekerja di luar negeri yang diukur dalam rupiah/ bulan. Gambaran tingkat pendapatan responden pasca bekerja di luar negeri masyarakat Kecamatan Sendang dapat dilihat pada Tabel 7 sebagai berikut.

\section{Tabel 7. Pendapatan Pasca Bekerja di Luar Negeri}

\begin{tabular}{clcc}
\hline No & Pendapatan Pasca Bekerja di Luar Negeri & F & \% \\
\cline { 4 - 4 } 1 & Rp. $400.000,00-<$ Rp. 600.00,00 & 14 & 14.0 \\
2 & Rp. 600.000,00-<Rp. 800.000,00 & 27 & 27.0 \\
3 & Rp. 800.000,00-Rp. 1.000.000,00 & 29 & 29.0 \\
4 & $>$ Rp. 1.000.000,00 & 13 & 13.0 \\
5 & Tidak bekerja (tidak berpenghasilan) & 17 & 17.0 \\
\hline & Jumlah & 100 & 100.0 \\
\hline
\end{tabular}

Berdasarkan Tabel 7 dapat dijelaskan bahwa tingkat pendapatan responden dikelompokkan menjadi lima kelompok berdasarkan dengan nilai maksimum dan nilai minimum pendapatan yang diperoleh oleh responden PMP pasca bekerja di luar negeri di Kecamatan Sendang. 
Responden yang memiliki penghasilan Rp. 800.000,00Rp. 1.000.000,00 sebanyak 29 responden $(29,0 \%)$ adalah yang paling tinggi dibandingkan kelompok responden dengan jumlah penghasilan lainnya. Responden yang memiliki tingkat pendapatan sebesar lebih dari Rp. 1.000.000,00 adalah tingkat pendapatan yang paling sedikit yang didapat oleh responden yaitu sebanyak tiga belas responden (13,0\%). Jadi sebagian besar PMP pasca bekerja di luar negeri berpenghasilan tinggi. Perbedaan tingkat penghasilan responden dikarenakan oleh perbedaan jenis pekerjaan responden yang berpengaruh terhadap besar kecinya tingkat pendapatan.

Dengan demikian maka dapat disimpulkan bahwa tingkat pendapatan PMP pasca bekerja di luar negeri yang paling tinggi adalah lebih dari Rp.1.000.000,00 per bulan, dengan jumlah responden sebanyak 13 orang $(14,0 \%)$. Sedangkan tingkat pendapatan PMP sebelum bekerja di luar negeri yang paling tinggi adalah lebih dari Rp.800.000,00 dan hanya satu responden saja. Jadi tingkat pendapatan PMP sebelum bekerja di luar negeri dengan setelah bekerja di luar negeri mengalami kenaikan yang cukup banyak. Untuk pengelompokan besarnya pendapatan yang paling banyak diperoleh responden pasca bekerja di luar negeri adalah sebesar Rp. 800.000,00-Rp. 1.000.000,00 yaitu sebanyak 29 responden $(29,0 \%)$ dan sangat jauh dibandingkan dengan penghasilan PMP sebelum bekerja di luar negeri yang mayoritas tidak mempunyai penghasikan yaitu sebanyak 54 responden $(54,0 \%)$. Jadi, seiring dengan bergantinya jenis pekerjaan yang lebih baik maka semakin tinggi pula pendapatannya.

Data tersebut di atas, diperkuat oleh pernyataan Suprapti yang menegaskan:

Selama kerja di Luar Negeri, saya bisa membeli sawah dan membangun rumah. Terus sisanya saya kumpulkan. Pas pulang saya gunakan untuk membuka 
toko dengan harapan tidak usah kembali ke Luar Negeri dan bisa hidup bersama keluarga. (Wawancara: Suprapti, 2018)

Pernyataan tersebut benar adanya, dan tidak hanya satu oranng PMP saja melainkan semua responden telah memiliki usaha ekonomi setelah mereka menjadi PMP. (Observasi peneliti, 2018). Adapun data terkait kepemilikan usaha sebagai pemaparan berikut.

\section{b. Kepemilikan Usaha Pasca Bekerja di Luar Negeri}

Kepemilikan usaha pascabekerja di luar negeri dalam penelitian ini adalah kepemilikan usaha oleh PMP setelah kembali ke daerah asal dimana jenis usaha tersebut memberikan lapangan pekerjaan untuk orang lain atau mampu menampung orang lain sebagai pekerja. Kepemilikan usaha pasca bekerja di luar negeri meliputi kepemilikan jenis usaha dan tempat usaha.

\section{1) Kepemilikan Jenis Usaha}

Dalam penelitian ini yang dimaksud dengan kepemilikan usaha adalah jenis usaha yang dimiliki PMP pasca bekerja di luar negeri yang mampu menyerap tenaga kerja lainnya. Berdasarkan hasil penelitianyang didapatkan dari keterangan responden, kepemilikan usaha pasca bekerja di luar negeri adalah seperti terdapat dalam tabel 9 berikut ini:

\section{Tabel 9. Kepemilikan Usaha Pasca Bekerja di Luar Negeri}

\begin{tabular}{clll}
\hline No & Kepemilikan Usaha & F & $\%$ \\
\cline { 4 - 4 } 1 & Bengkel & 1 & 1.0 \\
2 & Industri kerajinan & 2 & 2.0 \\
3 & Konveksi & 2 & 2.0 \\
4 & Pemerahan susu sapi perah & 6 & 6.0 \\
5 & Prod. Makanan ringan & 2 & 2.0 \\
6 & Salon & 1 & 1.0
\end{tabular}




\begin{tabular}{clcc}
7 & Tidak ada & 61 & 61.0 \\
8 & Toko & 17 & 17.0 \\
9 & Warung & 8 & 8.0 \\
\hline & Jumlah & 100 & 100.0 \\
\hline
\end{tabular}

Dari data yang terdapat dalam tabel di atas, dapat diketahui bahwa sebanyak 61 responden $(61,0 \%)$ tidak memiliki usaha yang mampu menyerap tenaga kerja dan kelompok ini merupakan kelompok dengan frekuensi responden yang paling banyak di antara kelompok responden lainnya berdasarkan pengelompokan menurut kepemilikan usaha. Sedangkan untuk jenis usaha yang paling sedikit respondennya adalah usaha bengkel dan salon yang masing-masing satu responden $(1,0 \%)$. Perbedaan jenis usaha yang didirikan PMP pascabekerja di luar negeri dipengaruhi oleh besar kecilnya modal usaha, bakat, minat, keterampilan serta kemampuan responden.

\section{2) Tempat Usaha}

Setiap kepemilikan jenis usaha PMP pascabekerja di luar negeri seperti di atas didirikan di suatu tempat yang telah disesuaikan situasi dan kondisinya dengan jenis usaha tersebut. Data tentang alamat tempat usaha PMP pasca bekerja di luar negeri dapat dilihat dari tabel 10 di bawah ini.

\section{Tabel 10. Alamat Tempat Usaha}

\begin{tabular}{clcc}
\hline No & Alamat Tempat Usaha & F & $\%$ \\
\cline { 1 - 2 } 1 & Di desa lain dalam satu kecamatan & 4 & 4.0 \\
2 & Di desa sendiri & 31 & 31.0 \\
3 & Di kabupaten lain & 1 & 1.0 \\
4 & Di kecamatan lain dalam satu kabupaten & 3 & 3.0 \\
5 & Tidak memiliki tempat usaha & 61 & 61.0 \\
\hline & Jumlah & 100 & 100.0 \\
\hline
\end{tabular}


Berdasarkan data yang ada pada tabel di atas, dapat diketahui tentang alamat usaha yang dimiliki oleh PMP yang telah pulang bekerja dari luar negeri. Sebanyak 62 responden $(62.0 \%)$ tidak memiliki usaha pasca bekerja di luar negeri seperti yang dimaksud dalam artikel ini jadi secara otomatis responden tersebut tidak memiliki tempat usaha.

Sedangkan untuk responden yang memiliki usaha yang paling banyak adalah usaha tersebut bertempat di desanya sendiri yaitu sebanyak 31 responden (31,0\%). Untuk yang paling sedikit usaha tersebut berada di kabupaten lain atau di luar Kabupaten Tulungagung dengan responden satu orang saja $(1,0 \%)$. Perbedaan tempat usaha PMP disesuaikan dengan situasi dan kondisi yang ada agar tepat dan sesuai untuk jenis usaha tersebut karena setiap jenis usaha mempunyai karakter berbeda dalam penempatannya.

Jika dianalisis lebih lanjut, jenis usaha yang paling banyak didirikan adalah sebanyak $17 \%$ responden atau 17 orang mendirikan toko. Sedangkan yang paling sedikit adalah jenis usaha yang bergerak dalam bidang jasa yaitu bengkel dan salon yang masing-masing sebesar $1 \%$ atau masing-masing satu responden. Sedangkan 61 responden yang merupakan kelompok responden paling banyak atau mayoritas dalam pengelompokan PMP dalam kepemilikan usaha, responden tersebut tidak memiliki jenis usaha yang manpu menyerap tenaga kerja. Perbedaan jenis usaha yang didirikan PMP pasca bekerja di luar negeri dipengaruhi oleh besar kecilnya modal usaha, bakat, minat, ketrampilan serta kemampuan responden.

Paparan data tersebut di atas menunjukkan terjadinya transformasi perekonomian desa, dari semula sebagai perempuan non produktif menjadi perempuan produktif dengan usaha ekonomi kreatif sebagai akibat dari terbuka wawasan setelah menjadi PMP. Hasil jerih 
payah tidak hanya disimpan dalam asset tak bergerak melainkan dalam asset bergerak berupa usaha ekonomi bahkan bisa menyerap tenaga kerja lain. Gambaran transformasi ini sebagaimana pernyataan salah satu PMP sebagai berikut:

\begin{abstract}
Dulu waktu sebelum kerja ke Luar Negeri saya hanya mengasuh anak, mengurus rumah tangga, dan ke ladang. Waktu senggang 'ngarit' untuk makanan lembu. Pikiran sempit tidak tahu mana-mana dan perkembangan dunia. Jadi diremehkan sama orang lain, termasuk keluarga. Sekarang sudah memiliki usaha warung begini walau kecil-kecilan tapi setiap hari dapat uang dan bisa dipakai untuk kebutuhan sehari-hari. Sekarang lebih percaya diri dan tidak dianggap lemah. Ini tidak hanya saya, perempuan yang lain juga sama. (Wawancara: Surti, 2018).
\end{abstract}

Paparan data dan wawancara tersebut di atas menunjukkan situasi terjadinya transformasi ekonomi, sebagaimana pendapat Yunus (2008) yang menyatakan bahwa transformasi ekonomi ditandai dengan perubahan kegiatan ekonomi yang berorientasi agraris lambat laun berubah nonagraris. Kegiatan ekonomi beralih pada kegiatan perdagangan dan kegiatan jasa. Demikian pula Todaro(2008)jugamenyatakan bahwa prosestransformasi ekonomi ditandai dengan menurunnya pangsa sektor primer atau sektor pertanian. Meningkatnya pangsa sektor sekunder seperti sektor industri dan pangsa sektor tersier atau jasa juga memberikan kontribusi yang mengingkat sejalan dengan pertumbuhan ekonomi.

\title{
3. Transformasi Pendidikan dalam Perspektif PMP
}

Pendidikan mempunyai peranan penting dalam kemajuan berbagai bidang. Pendidikan akan berpengaruh terhadap jenis pekerjaan dan tingkat pendapatan seseorang. Semakin tinggi pendidikan seseorang maka cara pandang untuk mendapatkan pekerjaan dan pendapatan semakin tinggi pula. 
Dari data yang berhasil penulis himpun, PMP yang pernah bekerja di luar negeri mempunyai tingkat pendidikan bermacam-macam, ada yang berpendidikan Sekolah Dasar (SD) saja, ada yang sampai SMP, ada juga yang sampai di tingkat SMA. Tingkat Pendidikan PMP yang pernah bekerja di luar negeri tersebut bisa dilihat pada tabel berikut:

Tabel 11. Tingkat Pendidikan PMP

\begin{tabular}{clcc}
\hline No & Pendidikan Terakhir & F & $\%$ \\
\cline { 4 - 4 } \multicolumn{1}{c}{ SD/Sederajat } & SDP/Sederajat & 15 & 15.0 \\
2 & SMP & 50 & 50.0 \\
3 & SMA/Sederajat & 35 & 35.0 \\
\hline & Jumlah & 100 & 100.0 \\
\hline
\end{tabular}

Tabel tersebut menunjukkan bahwa tingkat pendidikan para PMP yang pernah bekerja di luar negeri terbanyak adalah SMP/sederajat berjumlah 50 responden (50\%) dan yang paling sedikit adalah responden dengan pendidikan terakhir SD/ Sederajat yaitu sebanyak 15 responden (15\%). Maka dapatlah dikatakan bahwa tingkat pendidikan PMP yang pernah bekerja di luar negeri di Kecamatan Sendang masih rendah dan hal ini tentunya sangat berpengaruh terhadap jenis pekerjaan dan pendapatan mereka.

\section{a. Jumlah Kiriman Uang}

Jumlah kiriman uang yang dimaksud adalah jumlah kiriman uang yang dikirimkan PMP kepada keluarganya yang dikirimkan untuk setiap pengiriman dan dihitung dalam rupiah. Berikut ini adalah data tentang jumlah kiriman uang yang diberikan kepada keluarga responden.

Tabel 12. Jumlah Uang Kiriman Setiap Pengiriman

\begin{tabular}{cllcc}
\hline No & Jumlah Uang Kiriman Setiap Pengiriman & $\mathbf{f}$ & $\%$ \\
\cline { 1 - 3 } 1 & Rp.1.000.000,00-<Rp.2.000.000,00 & 8 & 8.0 \\
2 & Rp.2.000.000,00-<Rp.3.000.000,00 & 26 & 26.0
\end{tabular}




\begin{tabular}{clcc}
3 & Rp.3.000.000,00-<Rp.4.000.000,00 & 26 & 26.0 \\
4 & Rp.4.000.000,00-<Rp.5.000.000,00 & 22 & 22.0 \\
5 & $>$ Rp.5.000.000,00 & 18 & 18.0 \\
\hline & Jumlah & 100 & 100.0 \\
\hline
\end{tabular}

Berdasarkan data yang ada dalam tabel 12 diatas, dapat diketahui sebagian besar responden mengirimkan uang untuk setiap kiriman adalah sebesar Rp.2.000.000,00<Rp.3.000.000,00 dan Rp.3.000.000,00<Rp.4.000.000,00 yaitu masing-masing sebanyak 26 responden $(26,0 \%)$. Sedangkan sebagian kecil reponden yaitu 8 orang $(8,0 \%)$ mengirimkan uangnya sebesar Rp.1.000.000,00<Rp.2.000.000,00 dalam setiap kiriman. Besar kecilnya jumlah uang yang dikrim tergantung dengan gaji yang diterima oleh responden dan intensitas pengiriman uang yang diberikan untuk keluarga responden.

\section{b. Pemanfaatan Remiten Untuk Pendidikan}

Pendidikan mempunyai peranan yang sangat penting dalam kemajuan dalam berbagai bidang. Pendidikan pada dasarnya merupakan salah satu faktor yang sangat penting dalam sistem meningkatkan dan mengembangkan sumber daya manusia. Dari data yang diperoleh di lapangan tentang pemanfaatan remitensi untuk pendidikan dapat dilihat pada data yang terdapat pada tabel 13 di bawah ini.

Tabel 13. Pemanfaatan Remiten untuk Pendidikan

\begin{tabular}{llll}
\hline No & \% Pemanfaatan Untuk Pendidikan & F & $\%$ \\
\cline { 4 - 5 } 1 & $0 \%-9 \%$ & 20 & 20.0 \\
2 & $10 \%-19 \%$ & 70 & 70.0 \\
3 & $20 \%-29 \%$ & 10 & 10.0 \\
\hline \multicolumn{2}{l}{ Jumlah } & 100 & 100.0 \\
\hline
\end{tabular}


Berdasarkan data yang ada pada tabel 13 diatas, dapat diketahui besarnya prosentase pemanfaatan remiten untuk pendidikan keluarga PMP di daerah asal. Pemanfaatan yang paling banyak digunakan keluarga responden untuk pendidikan adalah sebesar 10\% sampai 19\% yaitu sebanyak tujuh puluh responden $(70,0 \%)$. Sedangkan keluarga responden yang paling sedikit memanfaatkan remitensi untuk pendidikan adalah sebanyak 10 responden $(10,0 \%)$ dengan jumlah pemanfaatan sebesar 20\% sampai 29\%. Maka dapat diketahui bahwa sebagian besar keluarga responden sudah memanfaatkan remitensi untuk pendidikan keluarga dan menyadari bahwa pendidikan adalah sesuatu yang sangat penting untuk mendapatkan perhatian.

Angka tersebut di atas menunjukkan terjadinya transformasi pendidikan, dimana ada kesadaran yang tumbuh dari PMP tentang pentingnya pendidikan yang direalisasikan dalam penyisihan dana remiten untuk alokasi pendidikan. Bahkan berdasar hasil wawancara mayoritas PMP menginginkan anaknya nanti sekolah sampai tingkat perguruan tinggi. Berikut pernyataan Narsih:

Walau saya hanya lulusan SMP, tapi saya tidak mau anak saya nanti seperti saya. Mereka harus sekolah sampai kuliah supaya nanti bisa jadi orang kantoran atau bekerja terhormat. Pokoknya gitu. Jangan sampai jadi bodoh seperti orangtuanya. (Wawancara: Narsih, 2018).

Perubahan mindset akan pentingnya pendidikan tersebut didukung fakta, bahwa saat ini mayoritas anak-anak PMP selain studi formal juga nonformal dengan mengikutkan les tambahan di kota. Tentunya inisiasi ini muncul berangkat darikesdaran pentingnya pendidikan bagianak-anakmereka. Transformasi mindset tentang pendidikan ini dilakukan PMP melalui manajemen pendidikan dengan cara penyisihan dana remiten khusus untuk biaya pendidikan. Fenomena ini memperkuat penelitian Widowati yang menyatakan bahwa 
faktor pendapatan pendapatan TKI yang cukup tingginamun tidak diimbangi dengan pengetahuan dan kemampuan mengelola keuangan yang baik maka akan sangat beresiko bagi anak dan keluarga yang ditinggalkan. (Widowati, 2019). Dan hal tersebut telah berhasil diminimalisir oleh para PMP di Kecamatan Sendang, dengan bukti adanya penyisihan dana remiten untuk pendidikan anak sebesar $20 \%$. Ini adalah suatu bentuk transformasi kesadaran pendidikan.

Kesadaran akan pendidikan ini tumbuh berangkat dari pengalaman ketika bekerja di luar negeri dan melihat fakta langsung bahwa hanya orang-orang yang memiliki pendidikan tinggi dan melek teknologi yang bisa mendapatkan posisi pekerjaan yang baik. Hal ini sebagaimana pendapat Mukhadis yang menyatakan bahwa transformasi pendidikan ditandai dengan pemenuhan kebutuhan bidang pendidikan berbasis pengetahuan (knowledge based education), pengembangan ekonomi berbasis pengetahuan (knowledge based economic), pengembangan dan pemberdayaan masyarakat berbasis pengetahuan (knowledge based social empowering), dan pengembangan dalam bidang industri pun berbasis pengetahuan (knowledge based industry). (Mukhadis, 2013:115) .

Di sisi inilah muncul kesadaran PMP akan pentingnya pendidikan dengan membekali generasi penerus berbasis pada knowledge, sehingga manajemen pendidikan untuk anak-anak PMP sudah direncanakan melalui tabungan pendidikan.

\section{Simpulan}

Transformasi sosial ekonomi mantan PMP luar negeri merupakan fenomena yang menarik untuk dikaji. Sebab dengan mengkajinya kita jadi tahu bahwa ternyata banyak dari mereka yang telah mengalami transformasi dan perubahan. Terdapat tiga transformasi yang di alami PMP di Kecamatan Sendang. Pertama, 
transformasi sosial yang ditandai dengan perubahan taraf hidup yang lebih baik, pergeseran profesi dari pekerjaan agraris menjadi pekerjaan non agraris, kelayakan tempat tinggal, perubahan status sosial, perubahan life style sebagai akibat dari infiltrasi nilai dan tujuan hidup yang tidak lagi homogen,terjadi kelonggaran norma sosial, dan kesadaran kolektif yang melemah. Kedua, transformasi ekonomi yang ditandai dengan meningkatnya pendapatan perempuan pasca menjadi PMP sebesar 20\% dan kepemilikan usaha ekonomi baik di desa tempat tinggal maupun di luar desa sebesar 39\%. Ketiga, transformasi kesadaran pendidikan yang ditandai dengan tumbuhnya kesadaran pentingnya pendidikan dengan menyekolahkan anak-anaknya sampai tingkat tertinggi sebagai wujud penyiapan generasi penerus berbasis pengetahuan. Aktualiasasi dari transformasi kesadaran pendidikan tersebut adalah pengalokasian remiten untuk dana pendidikan sebesar $20 \%$. 


\section{DAFTAR PUSTAKA}

Agustini, Rifa, (2012) “Karakteristik Tenaga Kerja Wanita Yang Pernah Bekerja di Luar Negeri dan dampak Remitensi Terhadap Keluarga Tenaga Kerja Wanita di Kecamatan Sepulu Kab. Bangkala". dalam http://karya ilmiah. um.ac.id/index.php/Geografi/article/view/22629

Albar, Achmad, "Kontribusi Pendapatan Tenaga Kerja Wanita Pada Usaha Pembuatan Tempe Terhadap Pendapatan Keluarga (Studi Kasus:Kelurahan Tanjung Sari, Kecamatan Medan Selayang),"https://jurnal.usu.ac.id/index.php/ ceress/article/viewFile/17499/7434

Arifin, Zainal.(2012). "Penelitian Pendidikan Metode dan

Paradigma Baru," Bandung: PT Remaja Rosdakarya.

Arikunto, Suharsimi. (2006)."Prosedur Penelitian Suatu Pendekatan Praktik,"Jakarta: PT Asdi Mahasatya. ..(2006)."Prosedur Penelitian Suatu Pendekatan Praktik,"Edisi Revisi VI, Jakarta: PT Rineka Cipta.

Asikin, Zainal, dkk. (1993). "Dasar-Dasar Hukum Perburuhan,"Jakarta: PT Raja Grafindo Persada.

Astuti, Sri. (2008)."Remitensi dan Sosial Ekonomi Keluarga Daerah Asal (Suatu Kajian PMP) di Desa Kananga dan Rasabou Kecamatan Bolo Kabupaten Bima NTB," Malang:Universitas Negeri Malang.

Bandiyono, Suko dan Indrawardani, Ken F. (2016). “Tinjauan Migrasi Penduduk Desa-Kota, Urbanisasi dan Dampaknya," Jurnal Kependudukan Indonesia Vol. 5 No 1 2010. Tersedia secara online dalam https://ejurnal. kependudukan.lipi.go.id/index.php/jki/article/view/99

Budijanto, dkk. (2004).“Faktor-Faktor Yang Mempengaruhi Pencurahan Waktu Kerja Wanita di Pedesaan Studi Kasus di Desa Tegal Gondo Kecamatan Karang Ploso Kabupaten Malang," Malang: Lemlit UM. 
Budijanto, dkk. (2007).“Peranan PMP Dalam Pengembangan Keluarga Sejahtera di Kotamadya dan Kabupaten Malang," Malang: Lemlit Universitas Negeri Malang.

Cook, Nancy (ed.).(2007). "Gender Relations in Global Perspective: Essential Readings," Kanada: Canadian Scholars' Press Inc.

Creswell,J.,(2012). “Educational Research:Planning, Conducting, and Evaluating Quantitative and Qualitative Research," (4thed.) Upper Saddle River, NJ: Pearson Education.

Direktorat Jenderal PPTKLN, (2006).“Peraturan Menteri Tenaga Kerja dan Transmigrasi R.I. Nomor: PER. 19/ MEN/V/2006," Jakarta: Direktorat jenderal PPTKLN.

Dwi Narwoko, \& Bagong Sunyoto, (2006). "Sosiologi Teks dan Pengantar Terapan," Jakarta: Kencana.

Fadhilla, arfa, (2017). “Analisis Transformasi Sosial Ekonomi Wilayah Peri Urban Di Kabupaten Kampar (Studi Kasus Desa Tarai Bangun Kecamatan Tambang)", dalam JOM Fekon, Vol. 4 No.1 (Februari)

Fakih, Mansour, (2013). Analisis Gender dan Transformasi Sosial, Cet. XV, Yogyakarta: Pustaka Pelajar.

Harjito, (2018). “Memoar Buruh Migran Perempuan Dan Media Perlawanan" dalam Palastren: Jurnal Studi Gender Vol. 10 No 1, Juni.

Kumalasari, Luluk Dwi, (2011). “Keharmonisan Keluarga TKW dalam Perspektif Gender (Studi di Donomulyo Malang)". dalam Humanity, Vol 6, No. 2.

SaktyoKuncoro,B(2018). "Faktor-FaktoryangMempengaruhi Pengambilan Keputusan Menjadi Tenaga Kerja Indonesia: Studi Kasus di Kabupaten Grobogan," Economics Development Analysis Journal, 6(4), 386-394. https://doi.org/10.15294/edaj.v6i4.22288. Tersedia secara online dalam https://journal.unnes.ac.id/sju/ index.php/edaj/article/view/22288 
Lexy J Moleong, (2005). "Metodologi Penelitian Kualitatif," Bandung: PT Remaja Rosdakarya.

Mantra, I.B.(2000).“Demografi Umum,” Yoyakarta: Pustaka Pelajar.

March, Candida, Smyth, and Mukhopadhya.(1999). "A Guide to Gender-Analysis Frameworks", UK: Oxfam GB.

Mc Connel, C.R. dan S.R. Brue. (1995). Mobility, Migration and Efficiency In Contemporary Labour Economics 4th ed," New York: McGraw-Hill.

Mukhadis, Amat, (2013). Sosok Manusia Indonesia Unggul dan Berkarakter dalam Bidang Teknologi Sebagai Tuntutan Hidup di Era Globalisasi. (online), (http://journal.uny. ac.id/index.php/jpka/article/view/1434)

Munanda, Aris (2013) Karakteristik, “Faktor Pendorong dan Dampak Perempuanmenjadi PMP Luar Negeri di Kecamatan Mranggen Kabupaten Demak," http:// journal.unnes.ac.id/nju/index.php/FIS.

Puspita, Ria.(2009).“Motivasi Pekerja Migran Perempuan Bekerja ke Luar Negeri dan Dampak Remitensi Terhadap Keluarga PMP di Kecamatan Cluring Kabupaten Banyuwangi," Malang: Universitas Negeri Malang.

Soekanto, Soerjono.(2010). Sosilogi Suatu Pengantar,PT. Raja Grafindo Persada: Jakarta.

Todaro, Michael. P dan Stephen C. Smith.(2008). Pembangunan Ekonomi Jilid I Edisi Kesembilan. Erlangga: Jakarta.

Tonnies, Ferdinand and Charles P. Loomies: "Gemeinschaft and Gesellschaft" dalam Reading in Sociology, editor Alfred Mc Clung Lee, Cetakan ke-5 Barnes \& Noble college Outline Series.

Undang-Undang Keimigrasian Republik Indonesia. (2005). Jakarta: PT. Armas Duta Jaya. 
Widowati, Evi., dan Cahyati, Widya Hary. (2019).Kejadian kekerasan Terhadap Anak Tenaga Kerja Indonesia Di Kabupaten Kendal dalam PALASTREN, 12(1). http:// journal.stainkudus.ac.id/index.php/Palastren/article/ view/3149/3688

Wijaya, Etistika Yuni, dkk.(2016). “Transformasi Pendidikan Abad 21 Sebagai Tuntutan Pengembangan Sumber Daya Manusia Di Era Global", Prosiding Seminar Nasional Pendidikan Matematika 2016 Universitas Kanjuruhan Malang.

Wilkes, Chris. (2005). "Kelas Menurut Bourdieu" dalam Harker, Richard. Cheelen Mahar dan Chris Wilkes. Tt. in (Habitus $\mathrm{x}$ Modal $)+$ ranah $=$ Praktik, Terjemahan by Pipit Maizier. Jogyakarta: Jalasutra.

Wulan, Tyas Retno, dkk. (2018). “Ayah Tangguh, Keluarga Utuh: Pola Asuh Ayah pada Keluarga Buruh Migran Perempuan di Kabupaten Banyumas," Jurnal Ilmu Keluarga dan Konsumen, Vol. 11, No. 2.

Yunus, Hadi Sabari.(2008). Dinamika Wilayah Peri-Urban Determinan Masa Depan Kota. Pustaka Pelajar: Yogyakarta. 